\title{
Src activation generates reactive oxygen species and impairs metabolism-secretion coupling in diabetic Goto-Kakizaki and ouabain-treated rat pancreatic islets
}

\author{
R. Kominato • S. Fujimoto • E. Mukai • Y. Nakamura • \\ K. Nabe • M. Shimodahira • Y. Nishi • S. Funakoshi • \\ Y. Seino $\cdot$ N. Inagaki
}

Received: 18 February 2008 / Accepted: 16 March 2008 / Published online: 1 May 2008

(C) Springer-Verlag 2008

\begin{abstract}
Aims/hypothesis $\mathrm{Na}^{+} / \mathrm{K}^{+}$-ATPase inhibition by ouabain suppresses ATP production by generating reactive oxygen species (ROS) and impairs glucose-induced insulin secretion from pancreatic islets. To clarify the signal-transducing function of $\mathrm{Na}^{+} / \mathrm{K}^{+}$-ATPase in decreasing ATP production by the generation of ROS in pancreatic islets, the involvement of $\mathrm{Src}$ was examined. In addition, the significance of Src activation in diabetic islets was examined.

Methods Isolated islets from Wistar rats and diabetic GotoKakizaki (GK) rats (a model for diabetes) were used. ROS was measured by 5-(and 6)-chloromethyl-2',7'-dichlorofluorescein fluorescence using dispersed islet cells. After lysates were immunoprecipitated by anti-Src antibody, immunoblotting was performed.

Results Ouabain caused a rapid $\mathrm{Tyr}^{418}$ phosphorylation, indicating activation of $\mathrm{Src}$ in the presence of high glucose. The specific Src inhibitor 4-amino-5-(4-chlorophenyl)-7( $t$-butyl)pyrazolo[3,4- $d]$ pyrimidine (PP2) restored the ouabain-induced decrease in ATP content and the increase in ROS production. Both PP2 and ROS scavenger restored the impaired insulin release and impaired ATP elevation in GK islets, but had no such effect in control islets. PP2 reduced
\end{abstract}

R. Kominato $\cdot$ S. Fujimoto $(\bowtie) \cdot$ E. Mukai $\cdot$ Y. Nakamura

K. Nabe $\cdot$ M. Shimodahira $\cdot$ Y. Nishi $\cdot$ S. Funakoshi $\cdot$ N. Inagaki

Department of Diabetes and Clinical Nutrition,

Graduate School of Medicine, Kyoto University,

54 Shogoin Kawahara-cho, Sakyo-ku,

Kyoto 606-8507, Japan

e-mail: fujimoto@metab.kuhp.kyoto-u.ac.jp

Y. Seino

Kansai Electric Power Hospital,

Osaka, Japan the high glucose-induced increase in ROS generation in GK islet cells but had no effect on that in control islet cells. Moreover, ouabain had no effect on ATP content and ROS production in the presence of high glucose in GK islets.

Conclusions/interpretation These results indicate that Src plays a role in the signal-transducing function of $\mathrm{Na}^{+} / \mathrm{K}^{+}$ATPase, in which ROS generation decreases ATP production in control islets. Moreover, ROS generated by $\mathrm{Src}$ activation plays an important role in impaired glucoseinduced insulin secretion in GK islets, in which Src is endogenously activated independently of ouabain.

Keywords ATP. GK rat $\cdot \mathrm{Na}^{+} / \mathrm{K}^{+}$-ATPase $\cdot$ Pancreatic islet . $\mathrm{ROS} \cdot \mathrm{Src}$

$\begin{array}{ll}\begin{array}{l}\text { Abbreviations } \\ \Delta \Psi_{\mathrm{m}}\end{array} & \begin{array}{l}\text { change in mitochondrial membrane potential } \\ \text { 5-(and 6)-chloromethyl-2',7'-dichlorofluores- } \\ \text { cein }\end{array} \\ \text { FCCP } & \begin{array}{l}\text { carbonyl cyanide } p \text {-trifluoromethoxyphenylhy- } \\ \text { drazone }\end{array} \\ \text { GK } & \begin{array}{l}\text { Goto-Kakizaki } \\ \text { JC-1 }\end{array} \\ \text { 5,5',6,6'-tetrachloro-1,1',3,3'-tetraethylbenzimi- } \\ \text { KRBB } & \begin{array}{l}\text { Krebs Ringer bicarbonate buffer } \\ \text { ROS }\end{array} \\ \text { PP2 } & \begin{array}{l}\text { reactive oxygen species } \\ \text { zolo[3,4- } d] \text { pyrimidine }\end{array}\end{array}$

Introduction

In pancreatic beta cells, intracellular glucose metabolism regulates exocytosis of insulin granules according to metabolism-secretion coupling, in which glucose-induced 
mitochondrial ATP production plays an essential role [1]. Since depletion of mitochondrial DNA abolishes the glucose-induced ATP elevation, mitochondria clearly are a major source of ATP production in pancreatic beta cells [2, 3]. Glucose-induced insulin secretion from beta cells is often impaired by exposure to high concentrations of fuels including glucose, NEFAs and ketone bodies, and by administration of diabetogenic pharmacological agents, all of which involve impaired glucose-induced ATP elevation in beta cells [4-11]. Thus, reduced mitochondrial ATP production plays an important role in impaired glucoseinduced insulin secretion.

Among the various agents that impair metabolismsecretion coupling in beta cells, the effects of reactive oxygen species (ROS) on glucose-induced insulin secretion have been extensively examined. Exposure to exogenous hydrogen peroxide $\left(\mathrm{H}_{2} \mathrm{O}_{2}\right)$, the most abundant ROS, reduces glucose-induced insulin secretion by impairing mitochondrial metabolism in beta cells. Transient exposure to $\mathrm{H}_{2} \mathrm{O}_{2}$ suppresses the hyperpolarisation of mitochondrial membrane potential [12], the increment in insulin secretion, and the increase in ATP content induced by glucose in pancreatic beta cells $[12,13]$.

However, little is known of the role of endogenous ROS in impaired glucose-induced insulin secretion. Recent studies have shown that mitochondria produce endogenous ROS in beta cells under physiological and pathophysiological conditions. Exposure to high glucose increases mitochondrial ROS production [14, 15], and the superoxide content of islets from Zucker diabetic fatty rats is higher than that from Zucker lean control islets under a basal level of glucose but are relatively insensitive to high glucose [14].

Ouabain, a well-known specific inhibitor of $\mathrm{Na}^{+} / \mathrm{K}^{+}$ATPase, decreases glucose-induced insulin release in the second phase [16]. We have found that ouabain decreases glucose-induced insulin release by reducing ATP content [17]. In addition, high glucose-induced hyperpolarisation of mitochondrial membrane potential was inhibited by ouabain. Furthermore, ouabain induced mitochondrial ROS production that was blocked by myxothiazol, an inhibitor of site III of the mitochondrial respiratory chain. Interestingly, these phenomena also occurred in $\mathrm{Ca}^{2+}$ - or $\mathrm{Na}^{+}$-depleted conditions. An antioxidant, $\alpha$-tocopherol, blocked the ouabain-induced ROS increase as well as the suppressive effect of ouabain on ATP production and insulin release. However, ouabain did not directly affect ATP production from the mitochondrial fraction. These results suggest that ouabain suppresses mitochondrial ATP production by generating mitochondrial ROS via signal transduction, independently of the intracellular cationic alternation, and has a suppressive effect on insulin secretion.
However, the details of $\mathrm{Na}^{+} / \mathrm{K}^{+}$-ATPase-mediated signal transduction in suppressing ATP production by the generation of mitochondrial ROS in pancreatic islets remain unknown. The binding of ouabain to $\mathrm{Na}^{+} / \mathrm{K}^{+}$-ATPase has been shown to activate Src, a non-receptor protein-tyrosine kinase, subsequently enhancing mitochondrial ROS production in cardiac myocytes [18-20]. In the present study, we investigated the involvement of $\mathrm{Src}$ in the signaltransducing function of $\mathrm{Na}^{+} / \mathrm{K}^{+}$-ATPase that reduces ATP production by generating mitochondrial ROS in pancreatic islets. In addition, the role of Src activation in impaired glucose-induced insulin secretion from diabetic islets was examined.

\section{Methods}

Animals Male Wistar and Goto-Kakizaki (GK) rats were obtained from Shimizu (Kyoto, Japan). The animals were fed standard laboratory chow ad libitum and allowed free access to water in an air-conditioned room with a $12 \mathrm{~h}$ light:12 h darkness cycle until used in the experiments. All experiments were carried out with rats aged 8-12 weeks. The animals were maintained and used in accordance with the Guidelines for Animal Experiments of Kyoto University.

Islet isolation and culture Islets of Langerhans were isolated from Wistar and GK rats by collagenase digestion as described previously [21]. Isolated islets were cultured for $12 \mathrm{~h}$ in RPMI 1640 medium containing 10\% (vol./vol.) FCS, $100 \mathrm{U} / \mathrm{ml}$ penicillin, $100 \mu \mathrm{g} / \mathrm{ml}$ streptomycin and $5.5 \mathrm{mmol} / \mathrm{l}$ glucose, at $37^{\circ} \mathrm{C}$ in humidified air containing $5 \% \mathrm{CO}_{2}$.

Solutions The medium used for islet isolation and preincubation of intact islets was Krebs Ringer bicarbonate buffer containing (in mmol/l) $129.4 \mathrm{NaCl}, 3.7 \mathrm{KCl}, 2.7 \mathrm{CaCl}_{2}$, $1.3 \mathrm{KH}_{2} \mathrm{PO}_{4}, 1.3 \mathrm{MgSO}_{4}, 24.8 \mathrm{NaHCO}_{3}$ (equilibrated with $5 \% \mathrm{CO}_{2}-95 \% \mathrm{O}_{2}, \mathrm{pH} 7.4$ ), and $0.2 \%$ (vol./vol.) BSA, hereafter referred to as KRBB. $\mathrm{Ca}^{2+}$-free media were prepared with $\mathrm{Ca}^{2+}$-free KRBB plus $1 \mathrm{mmol} / \mathrm{l}$ EGTA and $10 \mathrm{mmol} / \mathrm{l} \mathrm{HEPES}\left(\mathrm{Ca}^{2+}\right.$-free $\left.\mathrm{KRBB}\right)$.

Measurement of ATP content After groups of ten islets were preincubated in KRBB with $2.8 \mathrm{mmol} / 1$ glucose for $30 \mathrm{~min}$, they were batch-incubated for the indicated times in $0.5 \mathrm{ml}$ $\mathrm{Ca}^{2+}$-free $\mathrm{KRBB}$ with 2.8 or $16.7 \mathrm{mmol} / \mathrm{l}$ glucose with or without test materials. 4-amino-5-(4-chlorophenyl)-7(t-butyl)pyrazolo[3, 4-d]pyrimidine (PP2) and $\alpha$-tocopherol plus ascorbate were also included during preincubation. After immediate addition of $\mathrm{HClO}_{4}$, sonication in ice-cold water for $3 \mathrm{~min}$, and centrifugation, part of the supernatant fraction was mixed with HEPES and $\mathrm{Na}_{2} \mathrm{CO}_{3}$ and the ATP 
content in islets was determined by luminometry as previously described [22].

Fluorescence measurement of ROS production and change in mitochondrial membrane potential ROS production and change in mitochondrial membrane potential $\left(\Delta \Psi_{\mathrm{m}}\right)$ in dispersed islet cells under $\mathrm{Ca}^{2+}$-free conditions were measured by 5 -(and 6)-chloromethyl-2', $7^{\prime}$-dichlorofluorescein (CM-DCF) fluorescence and 5,5',6,6'-tetrachloro$1,1^{\prime}, 3,3^{\prime}$-tetraethylbenzimidazolcarbocyanine iodide (JC-1) fluorescence, respectively, as previously reported [17]. Fluorescence was corrected by subtracting parallel blanks in which islet cells were not loaded with probes, and is presented as a ratio with respect to the value at time zero.

Measurement of phosphorylation of Src Activation of Src in islets was determined by Western blotting after immunoprecipitation. After preincubation in KRBB containing $2.8 \mathrm{mmol} / 1$ glucose, islets were exposed to ouabain in $\mathrm{Ca}^{2+}$-free $\mathrm{KRBB}$ or $\mathrm{KRBB}$ with $16.7 \mathrm{mmol} / 1$ glucose for the indicated times. After washing with ice-cold PBS, the islets were solubilised in ice-cold lysis buffer containing $10 \mathrm{mmol} / \mathrm{l}$ Tris- $\mathrm{HCl}(\mathrm{pH}$ 7.2), $100 \mathrm{mmol} / \mathrm{l} \mathrm{NaCl}$, $1 \mathrm{mmol} / \mathrm{l}$ EDTA, $5 \mathrm{mmol} / \mathrm{l}$ sodium pyrophosphate, $0.5 \%$ sodium deoxycholate, $1 \%$ Nonidet P-40, protease inhibitor cocktail tablet (Roche, Penzberg, Germany) and phosphatase inhibitor cocktail set II (Calbiochem, Darmstadt, Germany) and sonicated. Cell lysates were centrifuged $\left(560,000 \times g\right.$ for $10 \mathrm{~min}$ at $\left.4^{\circ} \mathrm{C}\right)$ to obtain crude cell extracts. Protein content of the supernatant was measured and adjusted by the Bradford method. The supernatant was mixed with $4 \mu \mathrm{g}$ monoclonal anti-Src antibody (mouse monoclonal $\mathrm{IgG}_{1}$, clone GD11; Upstate, Lake Placid, NY, USA) and $30 \mu$ of washed Protein-G agarose beads, and gently rotated for $4 \mathrm{~h}$ at $4^{\circ} \mathrm{C}$. After washing three times with ice-cold lysis buffer, immunoprecipitates were dissolved in $30 \mu \mathrm{l}$ SDS-PAGE sample buffer $(50 \mathrm{mmol} / 1$ Tris$\mathrm{HCl}[\mathrm{pH}$ 6.8], 2\% SDS, 6\% 2-mercaptoethanol, 10\% glycerol, $1 \%$ bromophenol blue) and boiled for $5 \mathrm{~min}$ at $95^{\circ} \mathrm{C}$. The samples were subjected to electrophoresis on $10 \%$ SDS-polyacrylamide gels and transferred onto nitrocellulose membrane (Schleicher and Schuell, Keene, NH, USA). After blocking with PBS containing $0.1 \%$ Tween 20 and 5\% BSA (blocking buffer) overnight at $4{ }^{\circ} \mathrm{C}$, blotted membranes were incubated overnight with rabbit polyclonal anti-Src antibody (Santa Cruz Biotechnology, Santa Cruz, CA, USA) at $4^{\circ} \mathrm{C}$ in blocking buffer, and subsequently with anti-rabbit IgG horseradish peroxidase-conjugated secondary antibody (Amersham Biosciences, Tokyo, Japan) for $1 \mathrm{~h}$ prior to detection using ECL Plus (Amersham Biosciences). In the same membrane, the process was repeated for the following primary phosphospecific antibodies: rabbit polyclonal antibody to Src phosphorylated at $\mathrm{Tyr}^{418}\left(\mathrm{pY}^{418} \mathrm{Src}\right)$ or rabbit polyclonal antibody to Src phosphorylated at $\mathrm{Tyr}^{529}$ $\left(\mathrm{pY}^{529} \mathrm{Src}\right.$; Biosource, Camarillo, CA, USA) and mouse polyclonal anti-phosphotyrosine antibody (pY; clone 4G10; Upstate). Anti-mouse IgG horseradish peroxidase-conjugated secondary antibody (Amersham Biosciences) was used to detect the mouse primary antibody.

Measurement of glucose oxidation Glucose oxidation was measured as previously described [8]. Cultured islets were preincubated in KRBB with $2.8 \mathrm{mmol} / \mathrm{l}$ glucose in the presence or absence of Src inhibitor and antioxidants at $37^{\circ}$ $\mathrm{C}$ for $30 \mathrm{~min}$. Twenty-five islets in a small tube were incubated at $37^{\circ} \mathrm{C}$ for $90 \mathrm{~min}$ in $150 \mu \mathrm{l} \mathrm{Ca}{ }^{2+}$-free $\mathrm{KRBB}$ containing 2.8 or $16.7 \mathrm{mmol} / \mathrm{l}$ glucose, test materials, and [U- ${ }^{14} \mathrm{C}$ ]glucose $\left(1.85 \times 10^{4} \mathrm{~Bq}\right.$ per tube) (Amersham, Buckinghamshire, UK). After 90 min incubation, the reaction was stopped, and the dpm of trapped ${ }^{14} \mathrm{CO}_{2}$ in the hydroxide of hyamine 10-X (Packard, Meriden, CT, USA) was counted.

Measurement of insulin release, insulin content and DNA content Insulin release from cultured islets was monitored using static incubation as described previously [17]. After an aliquot of incubation medium for insulin assay was taken, the islets remaining were lysed to determine insulin and DNA contents as described previously [22].

Materials RPMI 1640 medium, carbonyl cyanide p-trifluoromethoxyphenylhydrazone (FCCP), $\alpha$-tocopherol and Lascorbic acid were purchased from Sigma (St Louis, MO, USA). Luciferin-luciferase was obtained from Turner Designs (Sunnyvale, CA, USA). CM-DCFH diacetate and JC-1 were purchased from Invitrogen (Eugene, OR, USA). PP2, herbimycin A and SU6656 were purchased from Calbiochem (La Jolla, CA, USA). All other agents including ouabain were obtained from Nacalai Tesque (Kyoto, Japan).

Statistical analysis Results are expressed as means \pm SE. Statistical significance was evaluated by an unpaired Student's t test. $p<0.05$ was considered significant.

\section{Results}

Effect of ouabain on ATP content Exposure to $16.7 \mathrm{mmol} / \mathrm{l}$ glucose for 15 min increased ATP content compared with that in the presence of $2.8 \mathrm{mmol} / \mathrm{l}$ glucose (at $15 \mathrm{~min}$, $16.7 \mathrm{mmol} / 1$ glucose: $17.1 \pm 0.9$ vs $2.8 \mathrm{mmol} / 1$ glucose: $8.5 \pm 0.2 \mathrm{pmol} /$ islet; $p<0.01$; Fig. 1a). For the $60 \mathrm{~min}$ incubation, ATP content remained high in the presence of $16.7 \mathrm{mmo} / \mathrm{l}$ glucose compared with that in the presence of $2.8 \mathrm{mmol} / 1$ glucose. Exposure to $1 \mathrm{mmol} / \mathrm{l}$ ouabain for 

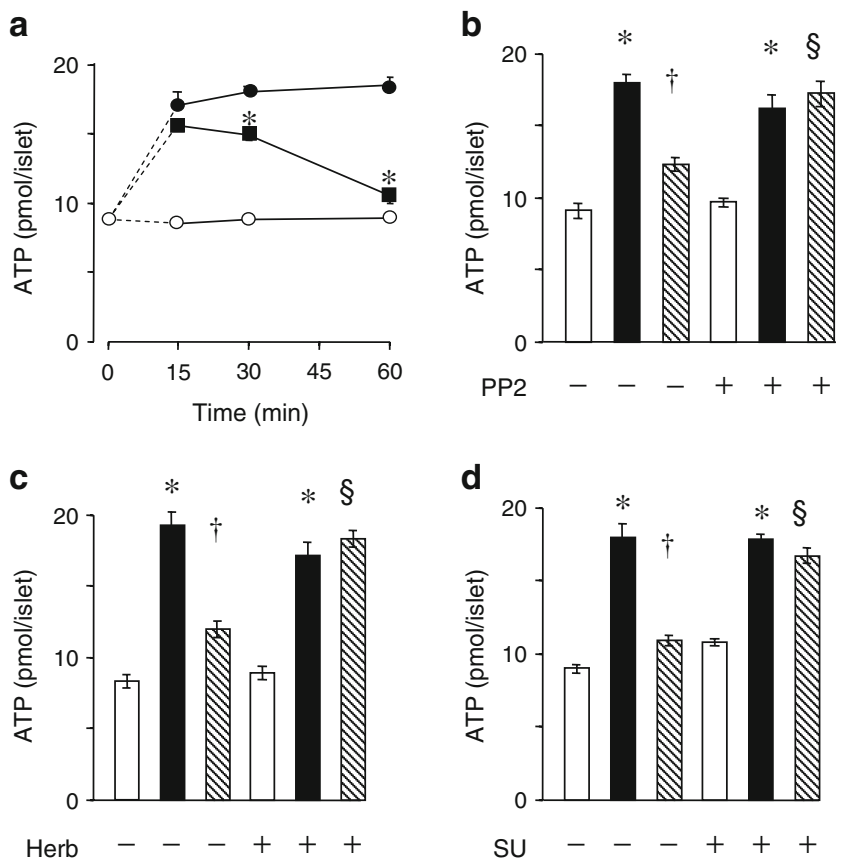

Fig. 1 Effects of Src inhibitors on ATP contents at high glucose after exposure to ouabain. a Time-course of ouabain-induced decrease of ATP contents. After preincubation with $2.8 \mathrm{mmol} / \mathrm{l}$ glucose, islets were incubated at $2.8 \mathrm{mmol} / 1$ glucose (white circles) or $16.7 \mathrm{mmol} /$ 1 glucose with (black squares) or without (black circles) $1 \mathrm{mmol} /$ 1 ouabain for the indicated times in $\mathrm{Ca}^{2+}$-depleted condition, and ATP contents were determined. Values are means \pm SE $(n=5) .{ }^{*} p<0.01$ vs $16.7 \mathrm{mmol} / 1$ glucose. $\mathbf{b}-\mathbf{d}$ Effects of Src inhibitors on ouabain-induced decrease of ATP contents in high glucose. After preincubation with $2.8 \mathrm{mmol} / \mathrm{l}$ glucose with or without $\mathrm{Src}$ inhibitors, islets were incubated for $60 \mathrm{~min}$ at $2.8 \mathrm{mmol} / 1$ glucose (white bars) or $16.7 \mathrm{mmol} / 1$ glucose with (hatched bars) or without (black bars) ouabain in the presence or absence of Src inhibitors under $\mathrm{Ca}^{2+}$ depleted condition, and ATP contents were determined. b Effect of $10 \mu \mathrm{mol} / 1 \mathrm{PP} 2$. c Effect of $1 \mu \mathrm{mol} / 1$ herbimycin A (Herb). d Effect of $5 \mu \mathrm{mol} / 1$ SU6656 (SU). Values are means \pm SE of $n=8(\mathbf{b}), n=10$ (c) and $n=8$ (d) determinations. ${ }^{*} p<0.01$ vs $2.8 \mathrm{mmol} / 1$ glucose; ${ }^{\dagger} p<0.01$ vs $16.7 \mathrm{mmol} / 1$ glucose; ${ }^{\S} p<0.01$ vs $16.7 \mathrm{mmol} / 1$ glucose plus ouabain without Src inhibitors

15 min did not suppress ATP content in the presence of $16.7 \mathrm{mmo} / \mathrm{l}$ glucose (at $15 \mathrm{~min}, 16.7 \mathrm{mmol} / 1$ glucose plus ouabain: $15.6 \pm 0.2 \mathrm{pmol}$ per islet vs $16.7 \mathrm{mmol} / \mathrm{l}$ glucose; $p=$ NS), but such exposure for 30 min decreased ATP content in the presence of $16.7 \mathrm{mmo} / \mathrm{l}$ glucose (at $30 \mathrm{~min}, 16.7 \mathrm{mmol} / \mathrm{l}$ glucose plus ouabain: $14.9 \pm 0.4$ vs $16.7 \mathrm{mmol} / \mathrm{l}$ glucose: $18.0 \pm 0.4$ pmol per islet; $p<0.01$; Fig. 1a). Furthermore, an exposure for $60 \mathrm{~min}$ profoundly suppressed ATP content at high glucose (at $60 \mathrm{~min}, 16.7 \mathrm{mmol} / \mathrm{l}$ glucose plus ouabain: $10.6 \pm 0.6$ vs $16.7 \mathrm{mmol} / \mathrm{l}$ glucose: $18.5 \pm 0.6 \mathrm{pmol}$ per islet; $p<0.01$; Fig. 1a).

In the presence of $10 \mu \mathrm{mol} / 1 \mathrm{PP} 2$, a Src inhibitor, $1 \mathrm{mmol} / \mathrm{l}$ ouabain failed to suppress ATP content in the presence of $16.7 \mathrm{mmol} / \mathrm{l}$ glucose $(16.7 \mathrm{mmol} / 1$ glucose plus ouabain with PP2: $17.2 \pm 0.9$ vs $16.7 \mathrm{mmol} / 1$ glucose with
PP2: $16.2 \pm 0.9$ pmol per islet; $p=\mathrm{NS}$ ) (Fig. 1b). ATP content in ouabain-treated islets at high glucose in the presence of PP2 was larger than that in the absence of PP2 $(16.7 \mathrm{mmol} /$ 1 glucose plus ouabain with PP2 vs $16.7 \mathrm{mmol} / \mathrm{l}$ glucose plus ouabain: $12.3 \pm 0.5$ pmol per islet; $p<0.01$ ). Similar results were observed in experiments using other Src inhibitors (Fig. 1c,d).

Effect of ouabain on ROS production Exposure to $1 \mathrm{mmol} /$ 1 ouabain for $15 \mathrm{~min}$ did not increase CM-DCF fluorescence, which represents ROS production, in the presence of $16.7 \mathrm{mmo} / \mathrm{l}$ glucose (at $15 \mathrm{~min}, 16.7 \mathrm{mmol} / 1$ glucose plus ouabain: $1.23 \pm 0.11$ vs $16.7 \mathrm{mmol} / 1$ glucose: $1.08 \pm 0.13$ relative units; $p=\mathrm{NS}$; Fig. 2a). However, such exposure for 30 or $60 \mathrm{~min}$ augmented CM-DCF fluorescence in the presence of $16.7 \mathrm{mmo} / 1$ glucose (at $30 \mathrm{~min}, 16.7 \mathrm{mmol} /$ 1 glucose plus ouabain: $1.58 \pm 0.10$ vs $16.7 \mathrm{mmol} / 1$ glucose: $1.24 \pm 0.07$ relative units; $p<0.05$; at $60 \mathrm{~min}, 16.7 \mathrm{mmol} /$ 1 glucose plus ouabain: $1.71 \pm 0.12$ vs $16.7 \mathrm{mmol} / 1$ glucose: $1.29 \pm 0.04$ relative units; $p<0.05$; Fig. $2 \mathrm{a}$ ). In the presence of $10 \mu \mathrm{mol} / 1 \mathrm{PP} 2,1 \mathrm{mmol} / \mathrm{l}$ ouabain did not increase CMDCF fluorescence in the presence of $16.7 \mathrm{mmol} / 1$ glucose ( $16.7 \mathrm{mmol} / \mathrm{l}$ glucose plus ouabain with PP2: $1.31 \pm 0.07$ vs $16.7 \mathrm{mmol} / \mathrm{l}$ glucose with $\mathrm{PP} 2: 1.33 \pm 0.05$ relative units; $p=$ NS) (Fig. 2b). PP2 reduced CM-DCF fluorescence of islet cells in the presence of $16.7 \mathrm{mmol} / \mathrm{l}$ glucose and $1 \mathrm{mmol} /$ 1 ouabain $(16.7 \mathrm{mmol} / \mathrm{l}$ glucose plus ouabain with PP2 vs $16.7 \mathrm{mmol} / \mathrm{l}$ glucose plus ouabain: $1.63 \pm 0.08$ relative units; $p<0.05$; Fig. 2b).
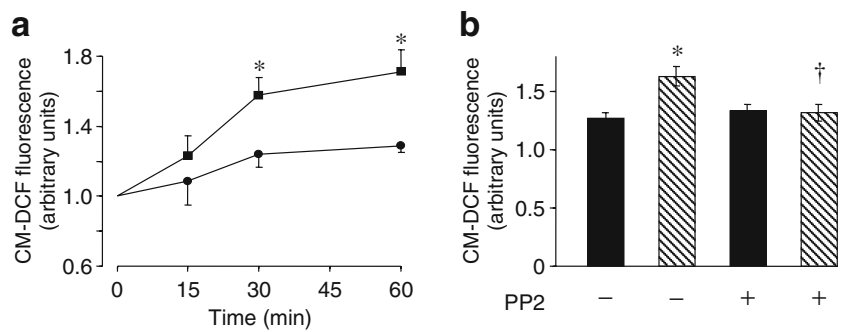

Fig. 2 Effects of Src inhibitor on ROS production at high glucose after exposure to ouabain. a Time-course of ouabain-induced increase of ROS production. After fluorescence measurements at time zero, the dispersed islet cells were incubated for the indicated times, with (squares) or without (circles) $1 \mathrm{mmol} / \mathrm{l}$ ouabain in the presence of $16.7 \mathrm{mmol} / 1$ glucose under $\mathrm{Ca}^{2+}$-depleted conditions. Values are means \pm SE $(n=4)$ as a ratio of values at time zero. $* p<0.05$ vs $16.7 \mathrm{mmol} / \mathrm{l}$ glucose. b Effects of Src inhibitor (PP2) on ouabaininduced increase of ROS production at high glucose. After CM-DCF fluorescence was determined at time zero, islet cells were incubated for $60 \mathrm{~min}$ with $16.7 \mathrm{mmol} / \mathrm{l}$ glucose with (hatched bars) or without (black bars) $1 \mathrm{mmol} / \mathrm{l}$ ouabain in the presence or absence of $10 \mu \mathrm{mol} /$ 1 PP2 under $\mathrm{Ca}^{2+}$-depleted conditions, and fluorescence was measured at $60 \mathrm{~min}$. Values are means $\pm \mathrm{SE}(n=4)$ as a ratio of values at time zero. ${ }^{*} p<0.05$ vs $16.7 \mathrm{mmol} / 1$ glucose. ${ }^{\dagger} p<0.05$ vs $16.7 \mathrm{mmol} /$ 1 glucose plus ouabain without PP2 
a

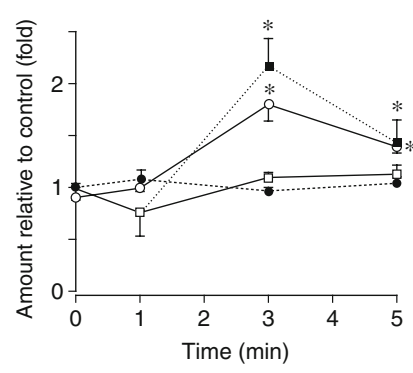

c

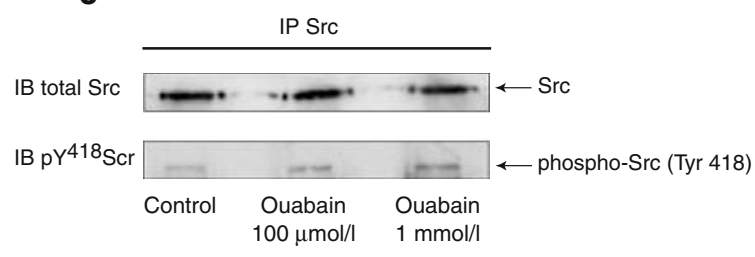

b

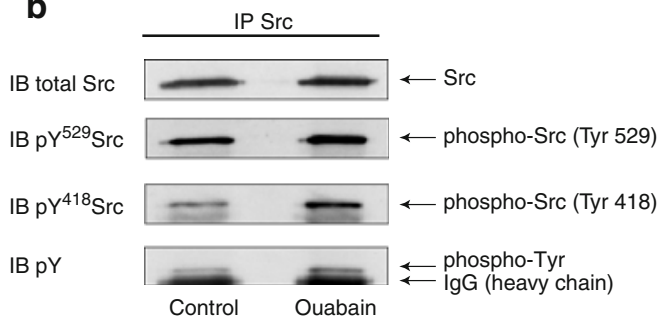

d

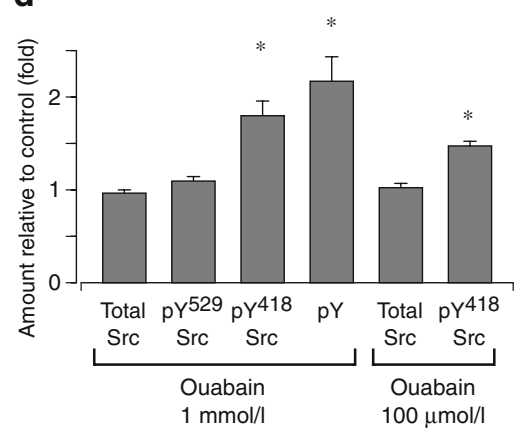

Fig. 3 Ouabain-induced Src tyrosine phosphorylation in islets under $\mathrm{Ca}^{2+}$-deprived condition in the presence of $16.7 \mathrm{mmol} / \mathrm{l}$ glucose. a Time-course of ouabain-induced Src tyrosine phosphorylation. After preincubation with $2.8 \mathrm{mmol} / \mathrm{l}$ glucose, islets were incubated with or without $1 \mathrm{mmol} / 1$ ouabain in the presence of $16.7 \mathrm{mmol} / 1$ glucose under $\mathrm{Ca}^{2+}$-depleted conditions for the indicated times. Islets were then lysed, immunoprecipitated with an anti-Src antibody, and assayed for Src tyrosine phosphorylation by Western blotting using $\mathrm{Tyr}^{418}$ phosphospecific Src antibody ( $\mathrm{pY}^{418} \mathrm{Src}$, white circles), Tyr ${ }^{529}$ phosphospecific Src antibody ( $\mathrm{pY}^{529} \mathrm{Src}$, white squares) or phosphotyrosine antibody (pY, black squares) by repetition of stripping and reprobing for the same blot. To ensure equal loading, total Src antibody (total Src, black circles) was also reprobed. Data are expressed relative to control $(16.7 \mathrm{mmol} / \mathrm{l}$ glucose without ouabain) value (means \pm SE, 0 min: $n=3,1$ min: $n=3,3 \min : n=8,5 \min : n=4$ ). ${ }^{*} p<0.01$ vs control (16.7 mmol/1 glucose without ouabain). b Representative immunoblots (IB) for total Src antibody, $\mathrm{Tyr}^{418}$ or $\mathrm{Tyr}^{529}$ phosphospecific Src antibodies $\left(\mathrm{pY}^{418} \mathrm{Src}\right.$ and $\left.\mathrm{pY}^{529} \mathrm{Src}\right)$ and phosphotyrosine antibody (pY) at $3 \mathrm{~min}$ in the same membrane. In the pY immunoblot, blots of IgG heavy chain derived from antibody used during immunoprecipitation were also observed. c Dose-dependent effect of ouabain on the level of Src tyrosine phosphorylation in islets. Representative immunoblot (IB) for total Src antibody and $\mathrm{pY}^{418} \mathrm{Src}$ antibody at $3 \mathrm{~min}$ in the same membrane. d Quantification data are expressed as means $\pm \mathrm{SE}$ of $n=6(100 \mu \mathrm{mol} / 1$ ouabain $), n=8(1 \mathrm{mmol} /$ 1 ouabain) determinations relative to control $(16.7 \mathrm{mmol} / 1$ glucose without ouabain) values. ${ }^{*} p<0.01$ vs control $(16.7 \mathrm{mmol} / 1$ glucose without ouabain). IP, immunoprecipitated
Effect of ouabain on Src phosphorylation Src activity is regulated by the phosphorylation of $\mathrm{Tyr}^{418}$ and $\mathrm{Tyr}^{529}$. Either a decrease in phosphorylation of $\mathrm{Tyr}^{529}$ or an increase in phosphorylation of $\mathrm{Tyr}^{418}$ stimulates Src kinase activity. Ouabain $(1 \mathrm{mmol} / \mathrm{l})$ caused a rapid activation of Src in the presence of $16.7 \mathrm{mmol} / 1$ glucose under $\mathrm{Ca}^{2+}$ deprived conditions. The maximum increase in $\mathrm{Tyr}^{418}$ phospholyration was observed $3 \mathrm{~min}$ after ouabain exposure (Fig. 3a). Ouabain caused a significant increase in Try ${ }^{418}$ and total tyrosine phosphorylation, but had no effect on Try $^{529}$ phosphorylation (at $3 \mathrm{~min}$, fold increase relative to control, $\mathrm{pY}^{418} \mathrm{Src}$ : $1.79 \pm 0.15, p<0.01$ vs control; total tyrosine phosphorylation (pY): $2.17 \pm 0.26, p<0.01$ vs control; $\mathrm{pY}^{529}$ Src: $1.09 \pm 0.04, p=\mathrm{NS}$ vs control; total Src: $0.96 \pm 0.03, p=\mathrm{NS}$ vs control) (Fig. 3b,d). A dose-dependent effect of ouabain on $\mathrm{Tyr}^{418}$ phosphorylation was also observed (100 $\mu \mathrm{mol} / \mathrm{l}$ ouabain, at $3 \mathrm{~min}$, fold increase relative to control, $\mathrm{pY}^{418} \mathrm{Src}: 1.47 \pm 0.05, p<0.01$ vs control; total Src: $1.02 \pm 0.04, p=\mathrm{NS}$ vs control; Fig. $3 \mathrm{c}, \mathrm{d})$. Such effects of ouabain on Src phosphorylation were also observed in a medium containing a physiological concentration of $\mathrm{Ca}^{2+}$ (fold increase relative to control, $\mathrm{pY}^{418} \mathrm{Src}$ : $1.59 \pm 0.10, p<0.01$ vs control; $\mathrm{pY}^{529} \mathrm{Src}: 1.07 \pm 0.07, p=\mathrm{NS}$ vs control; total Src: $0.96 \pm 0.06, p=\mathrm{NS}$ vs control) (Fig. 4).

Effect of ouabain on $\Delta \Psi_{m}$ To evaluate the effect of ouabain on $\Delta \Psi_{\mathrm{m}}$, JC-1 fluorescence was measured in the presence of $16.7 \mathrm{mmol} / 1$ glucose without $\mathrm{Ca}^{2+}$ (Fig. 5). After addition of $16.7 \mathrm{mmol} / \mathrm{l}$ glucose to the medium, fluorescence increased gradually, indicating hyperpolarisation of mitochondrial membrane potential, whereas the basal level of fluorescence was unchanged in the presence of $2.8 \mathrm{mmol} / \mathrm{l}$ glucose. Ouabain $(1 \mathrm{mmol} / \mathrm{l})$ significantly inhibited glucose-induced hyperpolarisation of mitochondrial membrane potential $30 \mathrm{~min}$ after administration (at $30 \mathrm{~min}, 16.7 \mathrm{mmol} / 1$ glucose plus ouabain: $1.04 \pm 0.03$ vs $16.7 \mathrm{mmol} / 1$ glucose: $1.51 \pm 0.05$ relative units; $p<0.01$ ). However, in the presence of $1 \mathrm{mmol} / \mathrm{l}$ ouabain with $16.7 \mathrm{mmol} / \mathrm{l}$ glucose, $10 \mu \mathrm{mol} / \mathrm{l} \mathrm{PP} 2$ reversed the effect of ouabain on $\Delta \Psi_{\mathrm{m}}$ and increased JC-1 fluorescence $30 \mathrm{~min}$ 
a

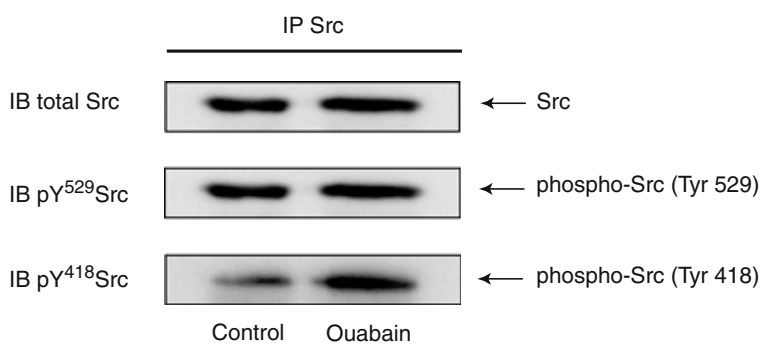

b

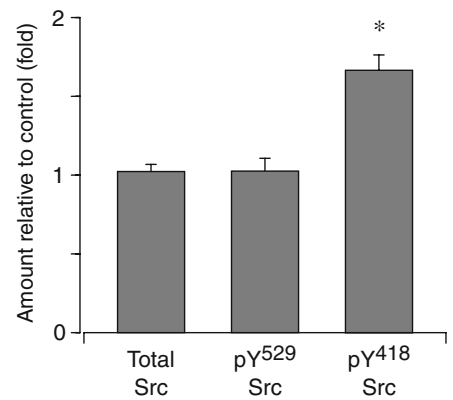

Fig. 4 Ouabain $(1 \mathrm{mmol} / \mathrm{l})$-induced Src tyrosine phosphorylation in islets in medium containing a physiological concentration of $\mathrm{Ca}^{2+}$ $(2.8 \mathrm{mmol} / \mathrm{l})$ in the presence of $16.7 \mathrm{mmol} / 1$ glucose. a Representative immunoblot (IB) for total Src antibody and $\mathrm{pY}^{418} \mathrm{Src}$ or $\mathrm{pY}^{529} \mathrm{Src}$

after administration $(16.7 \mathrm{mmol} / \mathrm{l}$ glucose plus ouabain with PP2: $1.41 \pm 0.07$ vs $16.7 \mathrm{mmol} / 1$ glucose plus ouabain: $1.04 \pm 0.03$ relative units; $p<0.01)$. JC-1 fluorescence decreased to below the basal level after the addition of $1 \mu \mathrm{mol} / 1 \mathrm{FCCP}$.

Effect of ouabain on glucose oxidation Glucose oxidation in islets in the presence of $16.7 \mathrm{mmol} / \mathrm{l}$ glucose was increased compared with that in the presence of $2.8 \mathrm{mmol} / 1$ glucose (Fig. 6). Glucose oxidation with $2.8 \mathrm{mmol} / \mathrm{l}$ glucose was not affected by $1 \mathrm{mmol} / \mathrm{l}$ ouabain (ouabain plus $2.8 \mathrm{mmol} / 1$ glucose: $7.6 \pm 1.0$ vs $2.8 \mathrm{mmol} / 1$ glucose: $5.6 \pm$ 0.6 pmol islet $\left.{ }^{-1} 90 \mathrm{~min}^{-1} ; p=\mathrm{NS}\right)$. However, glucose oxidation with $16.7 \mathrm{mmol} / 1$ glucose was suppressed by the agent $(16.7 \mathrm{mmol} / 1$ glucose plus ouabain: $30.0 \pm 4.3 \mathrm{vs}$ $16.7 \mathrm{mmol} / 1$ glucose: $53.9 \pm 6.1 \mathrm{pmol}^{\text {islet }}{ }^{-1} 90 \mathrm{~min}^{-1}$;

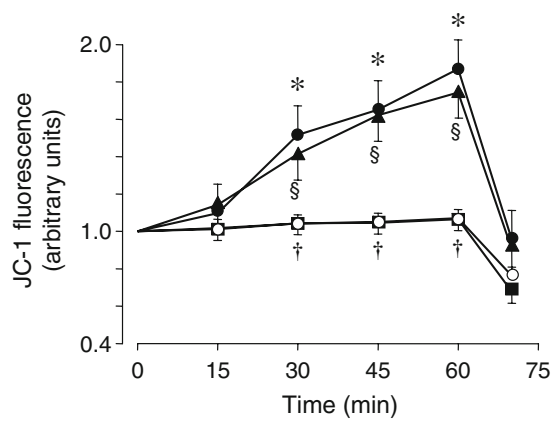

Fig. 5 Time-course effects of Src inhibitor (PP2) on ouabain-induced decrease of mitochondrial membrane potential at high glucose. After JC-1 was loaded, dispersed islet cells were preincubated for $30 \mathrm{~min}$ at $2.8 \mathrm{mmol} / \mathrm{l}$ glucose with or without $10 \mu \mathrm{mol} / 1 \mathrm{PP} 2$. At time zero, basal fluorescence was determined, and islet cells were incubated for the indicated time periods in $\mathrm{Ca}^{2+}$-depleted conditions at $2.8 \mathrm{mmol} /$ 1 glucose (white circles) or $16.7 \mathrm{mmol} / \mathrm{l}$ glucose with (black squares) or without (black circles) $1 \mathrm{mmol} / \mathrm{l}$ ouabain, or with $16.7 \mathrm{mmol} /$ 1 glucose with $1 \mathrm{mmol} / 1$ ouabain in the presence of $10 \mu \mathrm{mol} / 1 \mathrm{PP} 2$ (black triangles). At $60 \mathrm{~min}, 1 \mu \mathrm{mol} / \mathrm{l} \mathrm{FCCP}$ was added to the medium. Values are means $\pm \operatorname{SE}(n=6)$ as a ratio of values at time zero. ${ }^{*} p<0.01,2.8 \mathrm{mmol} / 1$ vs $16.7 \mathrm{mmol} / 1$ glucose; ${ }^{\dagger} p<0.01,16.7 \mathrm{mmol} /$ 1 glucose vs $16.7 \mathrm{mmol} / 1$ glucose + ouabain; ${ }^{\$} p<0.01,16.7 \mathrm{mmol} /$ 1 glucose + ouabain vs $16.7 \mathrm{mmol} / \mathrm{l}$ glucose + ouabain + PP2 antibodies at $3 \mathrm{~min}$ in the same membrane. b Quantification data from $n=5$ independent experiments. Data are expressed relative to control values (means $\pm \mathrm{SE}$ ). ${ }^{*} p<0.01$ vs control $(16.7 \mathrm{mmol} / 1$ glucose without ouabain). IP, immunoprecipitated

$p<0.01)$. In the presence of PP2 or $\alpha$-tocopherol plus ascorbate, ouabain did not affect glucose oxidation at $16.7 \mathrm{mmol} / 1$ glucose. Glucose oxidation with $16.7 \mathrm{mmol} / \mathrm{l}$ glucose and ouabain in the presence of PP2 or $\alpha$-tocopherol plus ascorbate was larger than that in the absence of PP2 and $\alpha$-tocopherol plus ascorbate $(16.7 \mathrm{mmol} / 1$ glucose plus ouabain with PP2: $50.2 \pm 4.5$ vs $16.7 \mathrm{mmol} / 1$ glucose plus ouabain: $30.0 \pm 4.3 ; p<0.01 ; 16.7 \mathrm{mmol} / 1$ glucose plus ouabain with $\alpha$-tocopherol plus ascorbate: $45.6 \pm$ $3.2 \mathrm{pmol}^{\text {islet }}{ }^{-1} 90 \mathrm{~min}^{-1}$ vs $16.7 \mathrm{mmol} / 1$ glucose plus ouabain; $p<0.01$ ).

Characteristics of animals and islets Table 1 shows the characteristics of the diabetes model GK rats and control Wistar rats used in this study. GK rats had lower body weight than control Wistar rats. In the fed state, GK rats had higher plasma glucose concentration. DNA content and

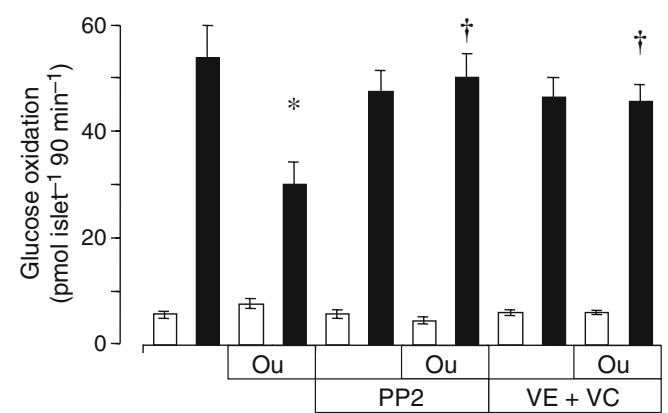

Fig. 6 Effects of Src inhibitor and ROS scavenger on ouabaininduced decrease of glucose oxidation at high glucose. After preincubation with $2.8 \mathrm{mmol} / 1$ glucose with or without $\mathrm{Src}$ inhibitor and ROS scavenger, islets were incubated for $90 \mathrm{~min}$ at $2.8 \mathrm{mmol} /$ 1 glucose (white bars) or $16.7 \mathrm{mmol} / \mathrm{l}$ glucose (black bars) with or without $1 \mathrm{mmol} / \mathrm{l}$ ouabain $(\mathrm{Ou})$ in the presence or absence of $\mathrm{Src}$ inhibitor $(10 \mu \mathrm{mol} / 1 \mathrm{PP} 2)$ and ROS scavenger $(100 \mu \mathrm{mol} / 1 \alpha-$ tocopherol plus $200 \mu \mathrm{mol} / 1$ ascorbate, $\mathrm{VE}+\mathrm{VC})$ under $\mathrm{Ca}^{2+}$-depleted conditions, and glucose oxidation was determined. Values are means \pm SE of $n=11$ determinations. ${ }^{*} p<0.01$ vs $16.7 \mathrm{mmol} / 1$ glucose; ${ }^{\dagger} p<$ 0.01 vs $16.7 \mathrm{mmol} / 1$ glucose plus ouabain without PP2 and $\alpha$ tocopherol plus ascorbate 
Table 1 Characteristics of control Wistar and diabetic GK rats used in the experiments

\begin{tabular}{lll}
\hline Characteristics & Control Wistar & GK \\
\hline Bodyweight (g) & $204 \pm 1(45)$ & $163 \pm 1^{* *}(78)$ \\
Non-fasting plasma glucose & $5.83 \pm 0.11(45)$ & $8.83 \pm 0.11^{* *}(78)$ \\
$\quad(\mathrm{mmol} / \mathrm{l})$ & & \\
Islet DNA content (ng/islet) & $13.5 \pm 0.6(80)$ & $13.5 \pm 0.7(80)$ \\
Islet insulin content (ng/islet) & $21.8 \pm 0.9(80)$ & $24.2 \pm 1.0(80)$ \\
\hline
\end{tabular}

Data are means $\pm \mathrm{SE}$ for the number of observations shown in parentheses

$* * p<0.01$ vs control Wistar rat

insulin content of islets derived from GK rats did not differ from those derived from control Wistar rats.

Effect of Src inhibition and ROS scavenger on insulin release and ATP content of $G K$ islets In the presence of $16.7 \mathrm{mmol} / 1$ glucose, insulin release from GK islets was reduced compared with control Wistar rats (GK: $1.78 \pm$ 0.25 vs Wistar: $4.36 \pm 0.23 \mathrm{ng}$ islet $^{-1} 30 \mathrm{~min}^{-1} ; p<0.01$ ) (Fig. 7a). PP2 and $\alpha$-tocopherol plus ascorbate had no effect on high glucose-induced insulin release from Wistar islets (Fig. 7a,b). However, high glucose-induced insulin release from GK islets was restored to control levels by Src inhibitor $(16.7 \mathrm{mmol} / \mathrm{l}$ glucose with PP2: $5.05 \pm 0.43$ vs $16.7 \mathrm{mmol} / 1$ glucose: $1.78 \pm 0.25 \mathrm{ng}$ islet $^{-1} 30 \mathrm{~min}^{-1} ; p<$ 0.01 ) and ROS scavenger (16.7 mmol/l glucose with $\alpha$ tocopherol plus ascorbate: $4.22 \pm 0.60$ vs $16.7 \mathrm{mmol} / 1$ glucose: $2.13 \pm 0.42 \mathrm{ng}$ islet $^{-1} 30 \mathrm{~min}^{-1} ; p<0.01$; Fig. 7a,b). The ATP content of GK islets in the presence of $2.8 \mathrm{mmol} /$ 1 glucose was not different from that in the presence of $16.7 \mathrm{mmol} / 1$ glucose $(2.8 \mathrm{mmol} / 1$ glucose: $7.0 \pm 0.4 \mathrm{vs}$ $16.7 \mathrm{mmol} / \mathrm{l}$ glucose: $8.3 \pm 0.7 \mathrm{pmol} /$ islet; $p=\mathrm{NS}$; Fig. 7c). In GK islets, ouabain did not suppress ATP content (16.7 $\mathrm{mmol} / 1$ glucose plus ouabain: $7.7 \pm 0.6 \mathrm{pmol} /$ islet vs $16.7 \mathrm{mmol} / \mathrm{l}$ glucose; $p=\mathrm{NS}$ ), while PP2 and $\alpha$-tocopherol plus ascorbate increased ATP content in the presence of
$16.7 \mathrm{mmol} / 1$ glucose $(16.7 \mathrm{mmol} / 1$ glucose with PP2: $12.3 \pm$ $0.7 \mathrm{pmol} /$ islet vs $16.7 \mathrm{mmol} / 1$ glucose, $p<0.01 ; 16.7 \mathrm{mmol} /$ 1 glucose with $\alpha$-tocopherol plus ascorbate: $11.0 \pm 0.7 \mathrm{pmol} /$ islet vs $16.7 \mathrm{mmol} / 1$ glucose, $p=0.01$; Fig. 7c).

Effect of Src inhibition and ROS scavenger on ROS production by $G K$ islet cells Ouabain had no effect on ROS production in the presence of high glucose in GK islet cells (at $60 \mathrm{~min}, 16.7 \mathrm{mmol} / \mathrm{l}$ glucose plus ouabain: $2.19 \pm 0.18$ vs $16.7 \mathrm{mmol} / 1$ glucose: $2.42 \pm 0.27$ relative units; $p=\mathrm{NS}$; Fig. 8a). However, PP2 and $\alpha$-tocopherol plus ascorbate decreased ROS production in the presence of high glucose in GK islet cells (at $60 \mathrm{~min}, 16.7 \mathrm{mmol} / 1$ glucose with PP2: $1.53 \pm 0.08$ relative units vs $16.7 \mathrm{mmol} / 1$ glucose, $p<0.05$; $16.7 \mathrm{mmol} / \mathrm{l}$ glucose with $\alpha$-tocopherol plus ascorbate: $1.46 \pm 0.04$ relative units vs $16.7 \mathrm{mmol} / 1$ glucose, $p<0.05$; Fig. 8b).

\section{Discussion}

In the present study, we show that Src plays a role in the signal-transducing function of $\mathrm{Na}^{+} / \mathrm{K}^{+}$-ATPase, by which ROS generation decreases ATP production in control islets. Moreover, ROS generated by Src activation plays an important role in impaired glucose-induced insulin secretion in GK islets, in which Src activation is ouabain independent.

In pancreatic beta cells, ROS production via nonmitochondrial and mitochondrial pathways has been proposed. ROS production from non-mitochondrial pathways including the hexosamine pathway [23], an unknown pathway from D-glyceraldehyde [24], and NADPH oxidase [25] have been reported. However, in most tissues, the major biological process leading to generation of ROS is the electron transport chain associated with the mitochondrial membrane [26, 27]. Recent studies have shown that beta cells exposed to high glucose produce mitochondrial $\operatorname{ROS}[14,15]$. Increase in ROS in the presence of high

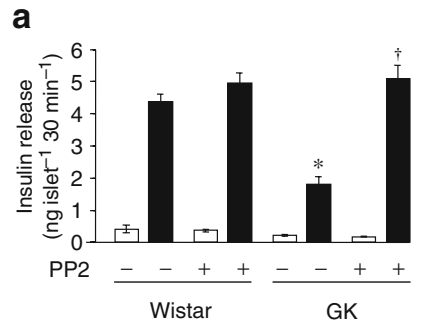

Fig. 7 Effects of Src inhibitor and ROS scavenger on insulin release and ATP contents in GK islets. After preincubation with $2.8 \mathrm{mmol} /$ 1 glucose for $30 \mathrm{~min}$, islets were incubated at $2.8 \mathrm{mmol} / \mathrm{l}$ glucose (white bars) or $16.7 \mathrm{mmol} / 1$ glucose (black bars) with or without test materials for $30 \mathrm{~min}(\mathbf{a}, \mathbf{b})$ or $60 \mathrm{~min}(\mathbf{c})$. PP2 and $\alpha$-tocopherol plus ascorbate were also included during preincubation. a Effects of $10 \mu \mathrm{mol} / 1 \mathrm{PP} 2$ on insulin release from control Wistar islets and GK b
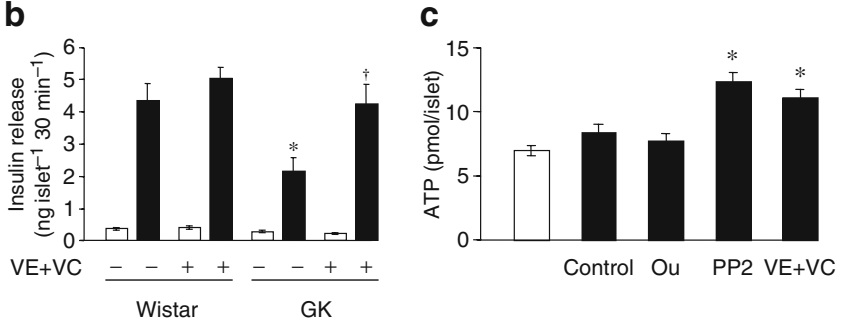

islets. Values are means $\pm \mathrm{SE}(n=10) .{ }^{*} p<0.01$ vs Wistar, $16.7 \mathrm{mmol} /$ 1 glucose; ${ }^{\dagger} p<0.01$ vs GK, $16.7 \mathrm{mmol} / 1$ glucose without PP2. b Effects of $100 \mu \mathrm{mol} / 1 \alpha$-tocopherol plus $200 \mu \mathrm{mol} / 1$ ascorbate $(\mathrm{VE}+\mathrm{VC}$ ) on ATP contents in GK islets. After incubation as indicated for $60 \mathrm{~min}$ in $\mathrm{Ca}^{2+}$-depleted conditions, ATP contents were determined. Values are means \pm SE $(n=10) .{ }^{*} p<0.01$ vs $16.7 \mathrm{mmol} / 1$ glucose 


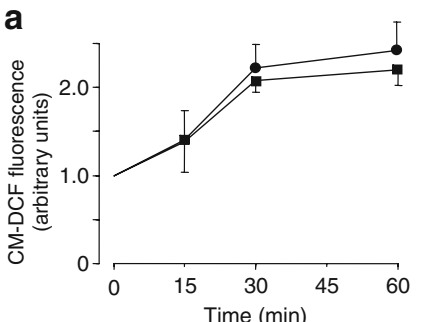

b

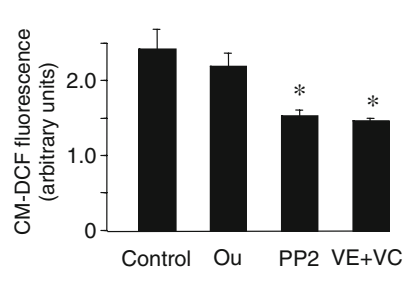

Fig. 8 Effects of ouabain, Src inhibitor and ROS scavenger on ROS production at high glucose in GK islet cells. a Effect of $1 \mathrm{mmol} / \mathrm{l}$ ouabain on the time-course of high glucose-induced increase of ROS production. After fluorescence measurements at time zero, the dispersed islet cells were incubated for the indicated times with (squares) or without (circles) $1 \mathrm{mmol} / \mathrm{l}$ ouabain in the presence of $16.7 \mathrm{mmol} / 1$ glucose under $\mathrm{Ca}^{2+}$-depleted conditions. Values are means $\pm \operatorname{SE}(n=3)$ as a ratio of values at time zero. b Effects of $1 \mathrm{mmol} / \mathrm{l}$ ouabain $(\mathrm{Ou}), 10 \mu \mathrm{mol} / \mathrm{l} \mathrm{PP} 2$ and $100 \mu \mathrm{mol} / 1 \alpha$-tocopherol plus $200 \mu \mathrm{mol} / 1$ ascorbate $(\mathrm{VE}+\mathrm{VC}$ ) on ROS production in the presence of $16.7 \mathrm{mmol} / \mathrm{l}$ glucose in GK islet cells. After CM-DCF fluorescence was determined at time zero, islet cells were incubated for $60 \mathrm{~min}$ with $16.7 \mathrm{mmol} / \mathrm{l}$ glucose in the presence or absence of test materials under $\mathrm{Ca}^{2+}$-depleted conditions, and fluorescence was measured at $60 \mathrm{~min}$. Values are means $\pm \mathrm{SE}(n=3)$ as a ratio of values at time zero. ${ }^{*} p<0.05$ vs $16.7 \mathrm{mmol} / 1$ glucose

glucose may be attributable to $\Delta \Psi_{\mathrm{m}}$-dependence of ROS formation, in which an exponential increase in ROS production is observed above $140 \mathrm{mV}$ in mitochondrial membrane potential [28]. However, in the present study, we show for the first time that there is an increase in mitochondrial ROS production via intracellular signal transduction in pancreatic islets. Thus, ROS production via the signal-transducing function of $\mathrm{Na}^{+} / \mathrm{K}^{+}$-ATPase does not necessarily require hyperpolarisation of mitochondrial membrane potential, as ouabain increases ROS production while the agent simultaneously inhibits hyperpolarisation of mitochondrial membrane potential.

$\mathrm{Src}$ is a $60 \mathrm{kDa}$ membrane-associated non-receptor tyrosine kinase that regulates various signal transduction pathways. Src production is widespread and has been demonstrated in pancreatic islets and in a beta cell line [29-32]. Its catalytic activity is controlled by tyrosine phosphorylation and protein-protein interaction. Phosphorylation of $\mathrm{Tyr}^{529}$ on Src holds the kinase in an inactive conformation through an intramolecular interaction with its Src homology 2 domain, whereas phosphorylation of $\mathrm{Tyr}^{418}$ activates Src by disrupting the intramolecular interaction and creating the substrate-binding site [33]. The binding of ouabain to the $\mathrm{Na}^{+} / \mathrm{K}^{+}$-ATPase causes rapid activation of $\mathrm{Src}$ in various cells including cardiac myocytes [34], smooth muscle cells $[34,35]$ and kidney epithelial cells [36] independently of the changes in intracellular ion concentrations. In the present study, ouabain stimulated $\mathrm{Tyr}^{418}$ phosphorylation but had no effect on $\mathrm{Tyr}^{529}$ phosphorylation, a phenomenon also observed in different types of cells [36]. Since ouabain-induced direct interaction between the $\mathrm{Na}^{+} / \mathrm{K}^{+}$-ATPase $\alpha_{1}$ subunit and Src is observed in kidney epithelial cells [36], ouabain-induced direct interaction between $\mathrm{Na}^{+} / \mathrm{K}^{+}$-ATPase and Src may well be involved in ouabain-induced Src phosphorylation in pancreatic beta cells.

A signal-transducing function of $\mathrm{Na}^{+} / \mathrm{K}^{+}$-ATPase via Src activation has been proposed recently in different types of cells including cardiac myocytes, A7r5 cells and HeLa cells [37]. The binding of ouabain to $\mathrm{Na}^{+} / \mathrm{K}^{+}$-ATPase activates Src, resulting in transactivation of the EGF receptor and increased mitochondrial production of ROS independently of changes in intracellular ion concentrations. In the present study, PP2, a specific Src inhibitor that reduces Src kinase activity and $\mathrm{Tyr}^{418}$ phosphorylation in rat islets [32], was found to decrease ouabain-induced ROS production, indicating that this signal-transducing function of $\mathrm{Na}^{+} / \mathrm{K}^{+}$ATPase plays a role in regulating mitochondrial ROS production in islets. However, the involvement of the transactivation of the EGF receptor in this pathway in islets remains unknown.

In a previous study, we found that ouabain reduces not only the increment in ATP content and the hyperpolarisation of mitochondrial membrane potential by glucose, but also the increment in $\mathrm{O}_{2}$ consumption by glucose [17]. Since increased $\mathrm{O}_{2}$ consumption occurs in uncoupling [38], ouabain-induced suppression of mitochondrial ATP production clearly is not mediated by uncoupling, and the suppression may derive from direct or indirect effects on the respiratory chain. Ouabain $(1 \mathrm{mmol} / \mathrm{l})$ was found to reduce glucose oxidation in the presence of $16.7 \mathrm{mmol} / \mathrm{l}$ glucose in islets in medium containing a physiological level of $\mathrm{Ca}^{2+}$ [39]. In the present study, $1 \mathrm{mmol} / \mathrm{l}$ ouabain also suppressed glucose oxidation in the presence of $16.7 \mathrm{mmol} / \mathrm{l}$ glucose in $\mathrm{Ca}^{2+}$-depleted conditions. Since ouabain-induced suppression of glucose oxidation was restored by ROS scavenger and by Src inhibitor, increased ROS production derived from Src activation may well suppress mitochondrial metabolism in the Krebs cycle, in which $\mathrm{CO}_{2}$ is released in the reaction mediated by dehydrogenases. This is supported by the fact that administration of $50 \mu \mathrm{mol} / 1 \mathrm{H}_{2} \mathrm{O}_{2}$, a concentration nearly equivalent to the $1 \mathrm{mmol} / \mathrm{l}$ ouabaininduced increase in ROS production [17], to mitochondria reduced activity of Krebs cycle enzymes including aconitase, $\alpha$-ketoglutarate dehydrogenase and succinate dehydrogenase, whose activities declined 96\%, 39\% and 37\%, respectively [40]. Considered together, these findings suggest that ouabain-induced mitochondrial ROS suppresses mitochondrial metabolism in the Krebs cycle, subsequently reducing NADH supply to the respiratory chain, hyperpolarisation of mitochondrial membrane potential, $\mathrm{O}_{2}$ consumption and ATP production.

We then investigated the role of ROS generated by Src activation in impaired glucose-induced insulin secretion in 
diabetes. One of the characteristics of type 2 diabetes is that the insulin secretory response of beta cells to glucose is selectively impaired [41]. In the GK rat, a genetic model of type 2 diabetes mellitus [42], glucose-induced insulin secretion is selectively impaired [43]. On single-channel recording, the glucose sensitivity of the beta cell $\mathrm{K}_{\text {ATP }}$ channel is remarkably reduced in GK rats, while the inhibitory effect of ATP on channel activity is not significantly different in control and GK rats [5]. The intracellular ATP elevation induced by high glucose is impaired in GK rats [44] as well as in patients with type 2 diabetes [45]. Thus, the impaired insulinotrophic action of glucose in beta cells of GK rats may be attributable to insufficient closure of the $\mathrm{K}_{\text {ATP }}$ channel because of deficient ATP production derived from impaired glucose metabolism. While there is evidence that islets in GK rats (a diabetes model) and human type 2 diabetes are oxidatively stressed $[46,47]$, the association between oxidative stress and impaired intracellular ATP elevation in islets is unclear. In the present study, both Src inhibitor and ROS scavenger restored the impairment in high glucose-induced insulin release and ATP elevation in GK islets but had no such effects in control islets. Moreover, Src inhibitor reduced the high glucose-induced increase in ROS generation in GK islet cells but had no effect on that in control islet cells. Ouabain had no effect on ATP content and ROS production in the presence of high glucose despite the prominent recovery effect of Src inhibitor in GK islets, suggesting that Src is endogenously activated independently of ouabain. Taken together, these results indicate that ROS generated by Src activation plays an important role in impaired glucoseinduced insulin secretion derived from impaired glucose metabolism in GK islets.

Acknowledgements The authors thank T. Yamaguchi for technical assistance. This study was supported by Scientific Research Grants, a Grant for Leading Project for Biosimulation from the Ministry of Education, Culture, Sports, Science and Technology of Japan, and a grant from Core Research for Evolutional Science and Technology (CREST) of Japan Science and Technology Cooperation.

Duality of interest The authors declare that there is no duality of interest associated with this manuscript.

\section{References}

1. Maechler P, Wollheim CB (2001) Mitochondrial function in normal and diabetic $\beta$-cells. Nature 414:807-812

2. Kennedy ED, Maechler P, Wollheim CB (1998) Effects of depletion of mitochondrial DNA in metabolism secretion coupling in INS-1 cells. Diabetes 47:374-380

3. Tsuruzoe K, Araki E, Furukawa N et al (1998) Creation and characterization of a mitochondrial DNA-depleted pancreatic $\beta$ cell line: impaired insulin secretion induced by glucose, leucine, and sulfonylureas. Diabetes 47:621-631
4. Takehiro M, Fujimoto S, Shimodahira M et al (2005) Chronic exposure to $\beta$-hydroxybutyrate inhibits glucose-induced insulin release from pancreatic islets by decreasing NADH contents. Am J Physiol 288:E372-E380

5. Tsuura Y, Ishida H, Okamoto Y et al (1993) Glucose sensitivity of ATP-sensitive $\mathrm{K}^{+}$channels is impaired in $\beta$-cells of the GK rat. A new genetic model of NIDDM. Diabetes 42:1446-1453

6. Hughes SJ, Faehling M, Thorneley CW, Proks P, Ashcroft FM, Smith PA (1998) Electrophysiological and metabolic characterization of single $\beta$-cells and islets from diabetic GK rats. Diabetes 47:73-81

7. Anello M, Lupi R, Spampinato D et al (2005) Functional and morphological alterations of mitochondria in pancreatic beta cells from type 2 diabetic patients. Diabetologia 48:282-289

8. Nabe K, Fujimoto S, Shimodahira M et al (2006) Diphenylhydantoin suppresses glucose-induced insulin release by decreasing cytoplasmic $\mathrm{H}^{+}$concentration in pancreatic islets. Endocrinology 147:2717-2727

9. Radu RG, Fujimoto S, Mukai E et al (2005) Tacrolimus suppresses glucose-induced insulin release from pancreatic islets by reducing glucokinase activity. Am J Physiol 288: E365-E371

10. Patane G, Anello M, Piro S, Vigneri R, Purrello F, Rabuazzo AM (2002) Role of ATP production and uncoupling protein-2 in the insulin secretory defect induced by chronic exposure to high glucose or free fatty acids and effects of peroxisome proliferatoractivated receptor- $\gamma$ inhibition. Diabetes 51:2749-2756

11. Joseph JW, Koshkin V, Saleh MC et al (2004) Free fatty acidinduced $\beta$-cell defects are dependent on uncoupling protein 2 expression. J Biol Chem 279:51049-51056

12. Maechler P, Jornot L, Wollheim CB (1999) Hydrogen peroxide alters mitochondrial activation and insulin secretion in pancreatic beta cells. J Biol Chem 274:27905-27913

13. Krippeit-Drews P, Kramer C, Welker S, Lang F, Ammon HP, Drews $\mathrm{G}$ (1999) Interference of $\mathrm{H}_{2} \mathrm{O}_{2}$ with stimulus-secretion coupling in mouse pancreatic $\beta$-cells. J Physiol 514:471-481

14. Bindokas VP, Kuznetsov A, Sreenan S, Polonsky KS, Roe MW, Philipson LH (2003) Visualizing superoxide production in normal and diabetic rat islets of Langerhans. J Biol Chem 278:9796-9801

15. Sakai K, Matsumoto K, Nishikawa T et al (2003) Mitochondrial reactive oxygen species reduce insulin secretion by pancreatic $\beta$ cells. Biochem Biophys Res Commun 300:216-222

16. Lambert AE, Henquin JC, Malvaux P (1974) Cationic environment and dynamics of insulin secretion. IV. Effect of ouabain. Horm Metab Res 6:470-475

17. Kajikawa M, Fujimoto S, Tsuura Y et al (2002) Ouabain suppresses glucose-induced mitochondrial ATP production and insulin release by generating reactive oxygen species in pancreatic islets. Diabetes 51:2522-2529

18. Kometiani P, Li J, Gnudi L, Kahn BB, Askari A, Xie Z (1998) Multiple signal transduction pathways link $\mathrm{Na}^{+} / \mathrm{K}^{+}$-ATPase to growth-related genes in cardiac myocytes. J Biol Chem 273:15249-15256

19. Xie Z, Kometiani P, Liu J, Li J, Shapiro JI, Askari A (1999) Intracellular reactive oxygen species mediate the linkage of $\mathrm{Na}^{+} /$ $\mathrm{K}^{+}$-ATPase to hypertrophy and its marker genes in cardiac myocytes. J Biol Chem 274:19323-19328

20. Liu J, Tian J, Haas M, Shapiro JI, Askari A, Xie Z (2000) Ouabain interaction with cardiac $\mathrm{Na}^{+} / \mathrm{K}^{+}$-ATPase initiates signal cascades independent of changes in intracellular $\mathrm{Na}^{+}$and $\mathrm{Ca}^{2+}$ concentrations. J Biol Chem 275:27838-27844

21. Fujimoto S, Ishida H, Kato S et al (1998) The novel insulinotropic mechanism of pimobendan: direct enhancement of the exocytotic process of insulin secretory granules by increased $\mathrm{Ca}^{2+}$ sensitivity in $\beta$-cells. Endocrinology 139:1133-1140 
22. Fujimoto S, Tsuura Y, Ishida H et al (2000) Augmentation of basal insulin release from rat islets by preexposure to a high concentration of glucose. Am J Physiol 279:E927-E940

23. Kaneto $\mathrm{H}, \mathrm{Xu} \mathrm{G}$, Song $\mathrm{KH}$ et al (2001) Activation of the hexosamine pathway leads to deterioration of pancreatic $\beta$-cell function through the induction of oxidative stress. J Biol Chem 276:31099-31104

24. Takahashi H, Tran PO, LeRoy E, Harmon JS, Tanaka Y, Robertson RP (2004) D-Glyceraldehyde causes production of intracellular peroxide in pancreatic islets, oxidative stress, and defective beta cell function via non-mitochondrial pathways. J Biol Chem 279:37316-37323

25. Tsubouchi H, Inoguchi T, Inuo $M$ et al (2005) Sulfonylurea as well as elevated glucose levels stimulate reactive oxygen species production in the pancreatic $\beta$-cell line, MIN6 - a role of NAD(P) $\mathrm{H}$ oxidase in $\beta$-cells. Biochem Biophys Res Commun 326:60-65

26. Yu BP (1994) Cellular defenses against damage from reactive oxygen species. Physiol Rev 74:139-162

27. Turrens JF (2003) Mitochondrial formation of reactive oxygen species. J Physiol 552:335-344

28. Kadenbach B (2003) Intrinsic and extrinsic uncoupling of oxidative phosphorylation. Biochim Biophys Acta 1604:77-94

29. Ohnishi M, Tokuda M, Masaki T et al (1994) Changes in annexin I and II levels during the postnatal development of rat pancreatic islets. J Cell Sci 107:2117-2125

30. Tejedo JR, Ramirez R, Cahuana GM, Rincon P, Sobrino F, Bedoya FJ (2001) Evidence for involvement of c-Src in the antiapoptotic action of nitric oxide in serum-deprived RINm5F cells. Cell Signal 13:809-817

31. Tejedo JR, Cahuana GM, Ramirez R et al (2004) Nitric oxide triggers the phosphatidylinositol 3-kinase/Akt survival pathway in insulin-producing RINm5F cells by arousing Src to activate insulin receptor substrate-1. Endocrinology 145:2319-2327

32. Cheng H, Straub SG, Sharp GW (2007) Inhibitory role of Src family tyrosine kinases on $\mathrm{Ca}^{2+}$-dependent insulin release. Am J Physiol 292:E845-E852

33. Roskoski R Jr (2004) Src protein-tyrosine kinase structure and regulation. Biochem Biophys Res Commun 324:1155-1164

34. Haas M, Askari A, Xie Z (2000) Involvement of Src and epidermal growth factor receptor in the signal-transducing function of $\mathrm{Na}^{+} / \mathrm{K}^{+}$-ATPase. J Biol Chem 275:27832-27837
35. Aydemir-Koksoy A, Abramowitz J, Allen JC (2001) Ouabaininduced signaling and vascular smooth muscle cell proliferation. J Biol Chem 276:46605-46611

36. Haas M, Wang H, Tian J, Xie Z (2002) Src-mediated interreceptor cross-talk between the $\mathrm{Na}^{+} / \mathrm{K}^{+}$-ATPase and the epidermal growth factor receptor relays the signal from ouabain to mitogenactivated protein kinases. J Biol Chem 277:18694-18702

37. Xie Z, Cai T (2003) $\mathrm{Na}^{+}-\mathrm{K}^{+}$-ATPase-mediated signal transduction: from protein interaction to cellular function. Mol Interv 3:157-168

38. Hutton JC, Malaisse WJ (1980) Dynamics of $\mathrm{O}_{2}$ consumption in rat pancreatic islets. Diabetologia 18:395-405

39. Sener A, Malaisse WJ (1991) Hexose metabolism in pancreatic islets. Regulation of D- $\left[6{ }^{14} \mathrm{C}\right]$ glucose oxidation by non-nutrient secretagogues. Mol Cell Endocrinol 76:1-6

40. Nulton-Persson AC, Szweda LI (2001) Modulation of mitochondrial function by hydrogen peroxide. J Biol Chem 276:23357-23361

41. Leahy JL, Bonner-Weir S, Weir GC (1992) Beta-cell dysfunction induced by chronic hyperglycemia. Current ideas on mechanism of impaired glucose-induced insulin secretion. Diabetes Care $15: 442-455$

42. Kimura K, Toyota T, Kakizaki M, Kudo M, Takebe K, Goto Y (1982) Impaired insulin secretion in the spontaneous diabetes rats. Tohoku J Exp Med 137:453-459

43. Portha B, Serradas P, Bailbe D, Suzuki K, Goto Y, Giroix MH (1991) $\beta$-cell insensitivity to glucose in the GK rat, a spontaneous nonobese model for type II diabetes. Diabetes 40:486-491

44. Hughes SJ, Faehling M, Thorneley CW, Proks P, Ashcroft FM, Smith PA (1998) Electrophysiological and metabolic characterization of single $\beta$-cells and islets from diabetic GK rats. Diabetes 47:73-81

45. Anello M, Lupi R, Spampinato D et al (2005) Functional and morphological alterations of mitochondria in pancreatic beta cells from type 2 diabetic patients. Diabetologia 48:282-289

46. Ihara Y, Toyokuni S, Uchida K et al (1999) Hyperglycemia causes oxidative stress in pancreatic $\beta$-cells of GK rats, a model of type 2 diabetes. Diabetes 48:927-932

47. Sakuraba H, Mizukami H, Yagihashi N, Wada R, Hanyu C, Yagihashi S (2002) Reduced beta-cell mass and expression of oxidative stress-related DNA damage in the islet of Japanese type II diabetic patients. Diabetologia 45:85-96 